\author{
꽃사슴의 녹용 성장기간 중 혈액 내 미네랄 및 \\ 효소활성 변화에 관한 연구 \\ 김명화* . 문상호* . 이창훈** . 전병태*
}

건국대학교 한국녹용연구센타*, 건국대학교 의과대학**

\title{
A Study on the Changes of Blood Mineral and Enzyme Activity During Growth Period of Velvet Antler in Korean Spotted Deer (Cervus Nippon)
}

\author{
M. H. Kim*, S. H. Moon*, C. H. Lee**, and B. T. Jeon* \\ Korea Nokyong Research Center, Konkuk University* \\ College of Medicine, Konkuk University**
}

\begin{abstract}
This study was aimed at investigating the change of blood mineral and enzyme activity during growth period of velvet antler in Korean spotted deer. Samples of blood, obtained from the jugular vein of twenty-five deer(4 to 6 year-old males), were taken in 10 days interval from just after casting to 50 days. Deer were randomly selected from the farm, and samples were analyzed for blood parameters like mineral concentration and enzyme activities. No significant differences found in calcium and phosphorus concentration in blood whereas sodium, potassium and chloride concentration were significantly changed with antler growth. There were no significant differences in alkaline phosphatase, aspartate aminotransferase, alanine aminotransferase, $\gamma$-glutamyl transferase and lactate dehydrogenase during growth of antler, but alkaline phosphatase concentration was increased with growth of antler, and the highest concentration was obtained on the 50 days after casting. Creatine kinase and lactate dehydrogenase activities for the deer tested in this experiment were higher than those of other animals.
\end{abstract}

(Key words : Blood mineral, Enzyme activity, Korean spotted deer)

\section{I 서 론}

사슴은 지구상에 존재하는 유각 포유동물 중 유일하게 뿔의 성장과 탈락이 매년 반복되는 뿔 발달 주기성을 갖고 있다. 수사슴에게 있어 이런 뿔 발달 cycle은 생리적인 요인과 환경적 인 요인, 영양적 요인의 복합적인 작용에 의해 일어나는 것으로 알려져 있다. 특히 뿔 성장 cycle과 내분비는 밀접한 관계가 있어 이와 관 련해 그간 많은 연구들이 수행되어져 왔다 (Garcia 등, 1997; Sempere 등, 1989; Sempere 등,
1986; Brown 등, 1983). 사슴 뿔의 발달 패턴은 포유동물의 연골 석회화 과정과 비슷한데 (Banks 등, 1983), 보통 포유류의 골은 두껍고 단단한 석회 조직인 피질 골이 표면 부위를 구 성하고, 75 j\%의 골수로 채워져 있는 해면 골이 내면 부위를 이루고 있다(Riggs와 Melton, 1986). 일반적으로 골세포는 조골세포(osteoblast), 골세포(osteocyte), 골내막세포(bone-lining cell), 파골세포(osteoclast)로 분류되며, 이 세포들의 작용으로 해면 골에서 체액과 접촉하여 골-칼 슘대사가 일어나면서 골의 형성, 성장, 재형성

Corresponding author : S. H. Moon, School of Life Resource Environment Science, Colleg. of Natr. Sci., Konkuk University, Chungju, 380-701, Korea. Tel: +82-43-840-3527, E-mail : moon0204@kku.ac.kr 
의 과정을 반복하며 골의 분화와 증식이 일어 난다(Bronner와 Stein, 1995). 한편 뿔의 발달과 석회화는 osteocalcin 농도와 alkaline phosphatase (ALK-P) 활성 증가에 따른 조골세포의 활성 증 가와 관련이 있는 것으로 알려져 있다(Brown 등, 1983; Eiben 등, 1984; Eems 등, 1988). 특히 사슴 뿔이 새롭게 형성될 때 필요한 미네랄은 골격에서 기원하고, 이때 사슴은 생리적으로 일시적인 골다공증을 일으킨다고 한다(Banks 등, 1968a, b). 또한 뿔의 발달을 위해서 장과 골격 으로부터 칼슘의 이행에 1,25-Dihydroxyvitamin $\left(1,25-(\mathrm{OH})_{2} \mathrm{D}\right)$ 이 관련될 수 있는데, 이는 fallow deer와 흰꼬리사슴에서 뿔 성장기간 동안에 vi$\operatorname{tamin} \mathrm{D}$ 의 대사 증가가 관찰됨으로써(Eiben 등, 1984; Eems 등, 1988) 이 사실을 뒷받침해 주고 있다. 조골세포, osteoprogenitor cells, chondrolasts, chondrocytes은 $1,25-(\mathrm{OH})_{2} \mathrm{D}$ 의 특이 수용체를 갖 는데 이는 사슴 뿔의 조골세포 형성과 활성에 역할을 하며(Chen 등, 1979; Manolagas 등, 1980), ALK-P의 합성이 증가하면서 분화된 조골 세포와 osteoblastic cell을 자극하여 chondrocytes 의 분열과 발현에 직접적으로 작용함으로서 뿔 기질 형성에 영향을 미친다(Kurihara 등, 1984; Fritsch 등, 1985; Takigawa 등, 1988)고 한다. 따 라서 혈액 내 ALK-P의 농도는 사슴 뿔 침착률 의 좋은 index이며, 따라서 ALK-P의 혈액 내 농 도와 뿔 발달 cycle과의 관계에 대한 연구도 보 고되고 있다(Graham 등, 1962; Morris와 Bubenik, 1983). Eems 등(1988)은 white-tailed deer로 실시 한 뿔 성장과 관련한 $1,25-(\mathrm{OH})_{2} \mathrm{D}, \mathrm{ALK}-\mathrm{P}$, hydroxyproline, osteocalcin의 혈액 내 농도에 대 한 연구에서, 성숙기의 사슴이나 완전히 성장 한 사슴보다 어린사슴에서 혈청 내 ALK-P 활 성과 hydroxyproline, osteocalcin 농도가 더 높았 다는 것을 보고하여 어린사슴에서 골대사가 증 가하고 있음을 나타내었고, 완전히 성장한 사 슴에서는 혈청 내 ALK-P 활성과 hydroxyproline 농도는 뿔 성장기간 동안에 증가했으며, 혈장 내 osteocalcin과 $1,25(\mathrm{OH})_{2} \mathrm{D}$ 는 뿔의 녹각화 동 안에 증가했음을 보고했다. 또한 뿔 발달과 관 련해서 white-tailed deer, sika deer 자록의 혈액 내 testosterone, androstenedione, thyroxine, 칼슘,
인, ALK-P의 농도를 측정한 결과 뿔의 button 성장시기에 testosterone 농도가 높았고, androstenedion은 botton이 녹각화 될 때 농도가 가장 높았으며, 뿔의 녹각화에는 ALK-P의 역할이 크 다는 것을 나타냈고, 어린 꽃사슴에서 인의 농 도와 어린 흰꼬리사슴에서 칼슘 농도가 높게 나타난 것은 종에 의한 차이라고 했다(Brown 등, 1983). 그런가 하면 thyroxin이 뿔의 성장개 시와 성장에 상조적인 역할을 하며, 칼슘과 인 의 수송체계에 ALK-P와 간접적으로 관련이 있 으며, 혈장 내 칼슘과 인의 농도는 일년 내내 일정하게 유지되었으나 어린 암사슴에서 칼슘 은 낮은 농도를, 인은 높은 농도였고, 칼슘과 인, 모두 나이의 영향은 없었다(Brown 등, 1983)는 연구보고도 있다. 이와 같이 사슴 뿔의 성장과 미네랄, 효소는 밀접한 관계에 있는데, 국내에서는 사슴의 혈액에 관한 연구가 일부 보고는 되고 있으나(신, 1987), 이는 일반적인 녹용 절각 시에 채취한 혈액을 분석한 자료로 서 녹용성장 기간 중의 변화에 대한 보고는 거 의 없는 실정이다.

따라서 본 연구는 집약적으로 사육되고 있는 꽃사슴의 녹용성장기간 중 혈액 내 미네랄의 함량과 생체 내 대사와 관련이 있는 효소의 활 성 변화를 조사하여 녹용성장과 미네랄 및 효 소와의 관련성 해석을 위한 기초자료로 제공하 고자 수행하였다.

\section{재료 및 방법}

\section{1. 실험동물}

본 실험은 2000년 4월부터 동년 8월까지 충 청북도 충주시에 소재하는 하나사슴 연구소에 서 실시하였다. 실험 가축은 $112 \mathrm{~m}^{2}$ 면적의 fence로 형성된 우리 내에서 사육중인 4 견생 꽃사슴 웅록 25두를 공시하였다. 급여사료는 발효사료(육림 부산물 사일리지)에 일정 비율의 농후사료, 루핀알곡, 갈잎, 알팔파베일을 혼합 하여 급여하였으며, 급여한 사료의 조단백질 함량은 평균 $21 \%$ 가 되도록 조절하였다. 사료는 아침과 저녁, 1 일 2회 급여하였고 미네랄 블록 
과 물은 자유 섭취토록 하였다.

\section{2. 혈액 채취}

녹용 성장기간동안의 혈액성상에 대한 분석 을 위해 낙각 직후부터 성장일수에 따라 10 일, 20일, 30 일, 40 일, 50 일(절각)에 각각 혈액 sample을 채취하였다. 혈액 채취는 근육이완 제(suxamethonium chloride)를 체중 $10 \mathrm{~kg}$ 당 1 $1.5 \mathrm{mg}$ 을 주사하여 사슴을 마취시킨 후, 1 회용 주사기를 사용하여 경정맥으로부터 $20 \mathrm{~m}$ 씩 채 취하였고, 채취한 혈액은 응고를 방지하기 위 해 헤파린(heparin)을 첨가한 용기에 담아 취 급하였으며, 현장에서 신속히 원심 분리하여 혈장을 분리한 후 분석시까지 영하 $80^{\circ} \mathrm{C}$ deep freezer에서 냉동 보관하였다.

\section{3. 혈액 분석}

혈액은 건국대학교 의과대학 부속병원 임상 병리학 연구실의 자동혈액분석기 EPX. ABBOTT SPECTRUM(ABBOTT LABORA TORIES, USA)을 사용하여 분석을 하였으며, alkaline phophatase (ALK-P), aspartate aminotransferase(AST), alanine aminotransferase(ALT), amylase, creatine kinase (CK), GGT, lactate dehydrogenase $(\mathrm{LDH})$ 등의 효 소와 $\mathrm{Ca}, \mathrm{P}, \mathrm{Na}, \mathrm{K}, \mathrm{Cl}$ 등의 무기물에 대한 분 석을 실시하였다.

\section{4. 통계 분석}

꽃사슴 혈액성분의 녹용성장기간별 평균값의 유의성 검정은 SAS package(Ver. 6.01, SAS Institute, 1985)를 이용하여 t-test를 통해 분석을 실시하였다.

\section{III 결과 및 고찰}

\section{1. 미네랄 농도}

녹용성장기간 중 꽃사슴의 혈액 내 미네랄 농도를 Fig. 1에 나타내었다. 낙각 직후 혈장
내 칼슘의 농도는 $9.17 \mathrm{mg} / \mathrm{dl}$ 이었으나, 낙각 후 일수가 경과함에 따라 증가하여 낙각 후 10 일 과 20 일에는 $9.77 \mathrm{mg} / \mathrm{dl}, 30$ 일에는 $9.9 \mathrm{mg} / \mathrm{dl}$ 로 녹 용성장 기간 중 가장 높았으며 이후 40 일에 $9.7 \mathrm{mg} / \mathrm{dl}, 50$ 일에 $8.9 \mathrm{mg} / \mathrm{dl}$ 로 녹용성장이 둔화되 면서 농도가 낮아졌으나 낙각 직후와 비교하여 녹용성장에 따른 유의차는 인정되지 않았다. 일반적으로 집약 사육되고 있는 사슴의 칼슘농 도는 연구에 따라 차이는 있으나 레드디어의 경우 $9.44-14.08 \mathrm{mg} / \mathrm{dl}(\mathrm{Knox}$ 등, 1988), $3.4-$ $15.16 \mathrm{mg} / \mathrm{dl}($ Wilson 등, 1982), rusa deer의 경우 8.0 - 11.32mg/dl(Audige, 1992)의 범위를 나타내 고 있었다. 칼슘 농도는 성별, 연령에 따라서 차이가 나타나는데, Chapple 등(1991)에 의하면 chital deer의 혈청 내 칼슘의 농도는 암컷 $9.2 \mathrm{mg} / \mathrm{dl}$, 임신한 암컷 $9.2 \mathrm{mg} / \mathrm{dl}$, 어린 암컷 $10 \mathrm{mg} / \mathrm{dl}$, 수컷 $9.6 \mathrm{mg} / \mathrm{dl}$, 어린 수컷 $10.8 \mathrm{mg} / \mathrm{dl}$, 신생 자록 $10.8 \mathrm{mg} / \mathrm{dl}$ 로 어린 사슴과 신생 자록 이 더 높은 농도를 나타냈으며, 이는 성장을 마친 동물보다 성장중인 동물에서 칼슘의 체내 필요량이 더 많다는 것을 시사하는 것으로 생 각된다. 그러나 계절적으로는 변화가 없었다고 했다. 일반적으로 녹용성장 형태는 전형적인 $\mathrm{S}$ 자 곡선을 나타내는데(Muir 등, 1987) 본 연구 에서 낙각 후 50일 경에 칼슘 농도가 떨어 진 것은 이 시기에 녹용성장이 둔화되고 있음

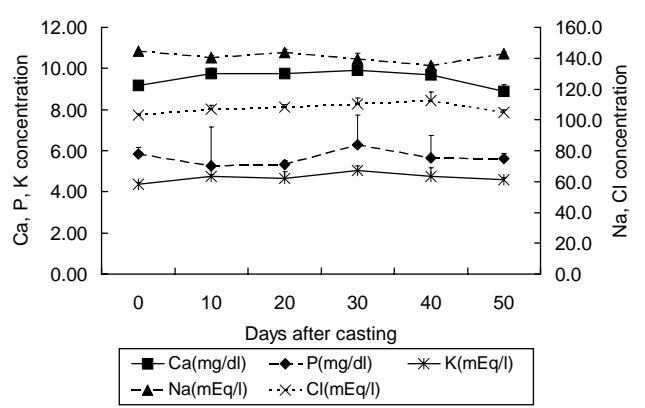

* Values are means, and vertical bars represent standard errors.

Fig. 1. Changes of calcium(Ca), phosphorus $(\mathrm{P})$, potassium $(\mathrm{K})$, sodium $(\mathrm{Na})$, and $\mathrm{Chl}$ oride $(\mathrm{Cl})$ concentration in blood plas ma during growth period of velvet a ntler in Korean spotted deer. 
을 나타내는 것으로, 즉 녹용성장이 왕성한 시 기에는 칼슘의 요구량도 많기 때문에 칼슘의 대사량이 증가하고 녹용성장이 둔화되는 40 일 이후에는 요구량의 감소에 따라 체내 칼슘 대 사량이 감소하여 그에 따른 혈액 내 칼슘의 농 도도 저하된 것으로 판단된다.

꽃사슴의 혈장 내 인의 농도는 낙각 직후 $5.84 \mathrm{mg} / \mathrm{dl}$ 였고 낙각 후 10 일에 $5.27 \mathrm{mg} / \mathrm{dl}, 20$ 일 에 $5.33 \mathrm{mg} / \mathrm{dl}$, 30 일에 $6.3 \mathrm{mg} / \mathrm{dl}, 40$ 일에 $5.63 \mathrm{mg} / \mathrm{dl}$, 50 일에 $5.61 \mathrm{mg} / \mathrm{dl}$ 을 나타내어 낙각 후 녹용성장 일수가 경과함에 따라 증감이 있었으나 성장기 간에 따른 유의차는 나타나지 않았다. 혈장 내 인의 농도는 비교적 일정하게 유지되지만 성 별, 연령에 따라 차이가 있는데, 암컷 chital deer의 혈청 내 평균 인 농도는 $6.81 \mathrm{mg} / \mathrm{dl}$, 임신 한 암컷 $6.81 \mathrm{mg} / \mathrm{dl}$, 어린 암컷 $8.05 \mathrm{mg} / \mathrm{dl}$, 수컷 $7.43 \mathrm{mg} / \mathrm{dl}$, 어린 수컷 $8.67 \mathrm{mg} / \mathrm{dl}$, 신생 자록은 $9.6 \mathrm{mg} / \mathrm{dl}$ 로 어린 사슴과 신생 자록에서 높은 농도를 나타냈다. Brown 등(1983)은 혈장 내 칼슘과 인의 농도는 연중 비교적 일정하게 유 지되었다고 보고하고 있는데, 본 연구에서도 녹용성장이라는 생리적인 상태의 변화에도 불 구하고 영양공급 수준이 일정하게 유지된 조건 에서는 혈액 내 칼슘과 인의 농도는 크게 변화 하지 않는 것으로 판단되나, 낙각 전과 절각 후 및 녹각화가 진행되는 기간의 농도를 측정 해 녹용성장기간의 농도와 비교해 볼 필요가 있을 것으로 여겨진다.

꽃사슴의 혈장 내 나트륨 농도는 낙각 직 후에 $144.75 \mathrm{mEq} / \mathrm{l}$ 를 나타내었고 낙각 후 10 일 에 $140.33 \mathrm{mEq} / 1$ 로$(\mathrm{I}$ < 01) 낮아졌으며 20일에 는 $143.67 \mathrm{mEq} / \mathrm{l}$ 로 증가하였다가 그 후 다시 감 소하여 30 일에 $139.67 \mathrm{mEq} / \mathrm{l}$, 40일에 $135.33 \mathrm{mEq} / \mathrm{l}$ ( $<0.001)$ 를 나타내어 녹용성장기간 중 가장 낮았고, 낙각 후 50 일에는 $143.06 \mathrm{mEq} / \mathrm{l}$ 로 다시 증가하였다. 혈장 내 나트륨은 체내에 절대적 인 과부족을 나타내지 않으며 체액의 나트륨과 수분의 평형으로 결정된다. 흰꼬리사슴의 혈청 내 나트륨 농도는 $137-143 \mathrm{mEq} / \mathrm{l}$ 의 범위였으며 (Glenn 등, 1987), 집약사육되고 있는 레드디어 의 혈청 내 나트륨 농도는 $70-220.0 \mathrm{mEq} / 1,109$ $154 \mathrm{mEq} / \mathrm{l}$ 범위였다고 보고되고 있다. 저단백질
사료를 급여한 사슴에서 혈청 내 나트륨 농도 가 증가했다는 보고도 있으나(Seal 등, 1987), Glenn 등(1987)은 고단백질 - 고에너지(crude protein 13.0\%), 저단백질 - 고에너지(crude protein $6.9 \%$ 사료로 조건을 달리하여도 혈청 내 나트 륨 농도에는 변화가 없었다고 보고했으며, 이 는 Anderson 등(1972)이 계절적인 나트륨 농도 변화에 섭취한 초목류의 영향이 없었다는 보고 와도 일치하고 있다. 본 연구에서도 녹용성장 기간 중에 다소의 함량 증감은 있었으나 그리 큰 변화는 아니었기 때문에 꽃사슴의 혈액 내 나트륨의 함량은 녹용성장 기간에도 변화가 크 지 않은 것으로 판단된다.

칼륨의 혈장 내 농도는 낙각 직후에는 4.37 $\mathrm{mEq} / \mathrm{l}$ 를 나타내었고 낙각 후 10 일에 $4.73 \mathrm{mEq} / \mathrm{l}$, 20 일에 $4.67 \mathrm{mEq} / 1,30$ 일에 $5.03 \mathrm{mEq} / \mathrm{l}(\mathrm{I}<0.05)$ 로 가장 높았으며 그 후 감소하여 낙각 후 40 일에 $4.73 \mathrm{mEq} / \mathrm{l}, 50$ 일에 $4.58 \mathrm{mEq} / \mathrm{l}$ 를 각각 나타내었 다. 겨울 동안 $13-25 \%$ 의 체중감소가 있었던 reindeer의 혈청 내 칼륨 농도는 체중 감소와 함께 저하되는 경향을 나타내어 보통 3.2-4.5 $\mathrm{mmol} / \mathrm{l}$ 의 농도범위 내에 있었으며, 이는 사료로 급여한 lichen에 함유된 칼륨의 함량이 낮기 때 문이라고 보고하였는데(Soveri 등, 1992), 이러 한 결과는 겨울동안 체중감소가 $11 \%$ 와 $21 \%$ 였 던 사슴에서 칼륨 농도가 감소했다는 보고 (Seal 등, 1972)와도 일치하고 있다. 이러한 현 상들은 반추가축에서 사료의 칼륨 함량은 혈청 내 칼륨의 농도에 직접적으로 영향을 미친다는 것을 시사한다. 또한 흰꼬리사슴에게 고에너지 사료를 급여하였을 때 사슴의 혈청 내 평균 칼 륨 농도는 $3.6 \mathrm{mEq} / 1$ 였으나, 절식시킨 사슴의 혈 청 내 평균 칼륨 농도는 $3.1 \mathrm{mEq} / \mathrm{l}$ 였던 것이 사료를 재 급여하자 $3.8 \mathrm{mEq} / 1$ 로 증가하였다는 연구결과가 이를 뒷받침하고 있다(DelGiudice 등, 1987). 즉 혈장 내 나트륨 농도는 사료와 관련이 없으나, 칼륨 농도는 사료조건과 관련 이 있음을 나타내고 있으며, 본 연구에서와 같 이 일정한 수준의 영양관리가 이루어지고 있는 사슴은 녹용성장 기간이라 하더라도 이들의 농 도에는 커다란 변화가 없다고 판단된다.

꽃사슴의 혈장 내 염소의 농도는 낙각 직후 
에 $103 \mathrm{mEq} / \mathrm{l}$ 를 나타내었으며, 낙각 후 10 일에 $107.0 \mathrm{mEq} / \mathrm{l}, \quad 20$ 일에 $108.33 \mathrm{mEq} / \mathrm{l}(\mathrm{I}<0.05), 30$ 일 에 $110.33 \mathrm{mEq} / \mathrm{l}(\mathrm{I}<0.01), 40$ 일에 $112.67 \mathrm{mEq} / \mathrm{l}$, 50 일에 $104.94 \mathrm{mEq} / 1$ 를 각각 나타내어 녹용성장 기간에 따라 염소농도가 약간 증가되고 있는 것으로 나타났다. Soveri 등(1992)의 보고에 의 하면 겨울 동안(11월 4월) $13 \sim 25 \%$ 의 체중 감소가 있었던 reindeer의 혈청 내 염소의 평균 농도는 체중 감소가 진행되면서 증가하는 경향 을 나타내며 그 농도 범위는 $100-117 \mathrm{mmol} / \mathrm{l}$ 이 었으며 이듬해 4 월에는 다시 처음의 농도를 회 복하여 나트륨 농도 변화와 일치하고 있다. 그 러나 본 연구에서는 녹용성장 기간 중 나트륨 과 염소 농도의 증감이 같은 경향은 아니었으 나 다른 사슴들과 비교했을 때 큰 차이를 나타 내지는 않았다. 이상 녹용성장기간 중 혈장 내 칼슘, 인, 나트륨, 칼륨, 염소 등의 미네랄 함량 을 경시적으로 검토한 바 특기할만한 변동패턴 은 발견할 수 없었다. 이는 정상적인 영양관리 를 하고 있는 사슴이라면 왕성한 녹용성장기간 중에도 혈액 내 미네랄의 성분에는 큰 변화가 나타나지 않는 것으로 판단된다.

\section{2. 효소 활성}

Fig. 2에 꽃사슴의 낙각 후 녹용성장에 따른 혈액 내의 효소 활성치에 대한 분석 결과를 나 타내었다.

꽃사슴의 혈액 내 Alkaline phosphate(ALK-P) 의 활성치는 낙각 직후 $155.92 \mathrm{U} / \mathrm{L}$ 이었으나, 낙각 후 성장이 진행됨에 따라 지속적으로 증가하여 낙각 후 10 일에 $242.67 \mathrm{U} / \mathrm{L}, 20$ 일에 243.33U/L, 30일에 264.67U/L, 40일에 260.67U/L, 50 일에 $329.81 \mathrm{U} / \mathrm{L}(\mathrm{I}<0.01)$ 을 각각 나타내었다. ALK-P는 골 성장과 관련이 있는 효소로 골 신 생(remodeling)이 있는 경우에는 ALK-P 활성치 가 증가하나 골 파괴만 있고 골 신생이 없는 경우에는 ALK-P는 증가하지 않는다(이와 이, 1996). Chapple 등(1991)은 수컷 chital deer의 평 균 혈청 내 ALK-P 농도는 219U/L였으나 뿔 성 장 60일 후에는 960U/L에 이르렀으며 이때 육 경 $2 \mathrm{~cm}$ 위쪽을 제거했을 때, ALK-P 농도는 급

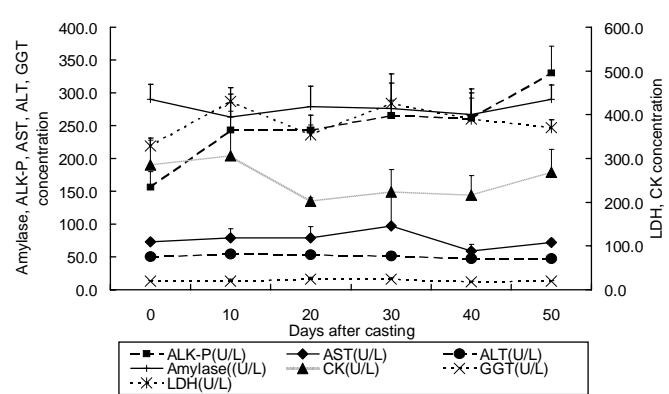

* Values are means, and vertical bars represent standard errors.

Fig. 2. Changes of alkaline phosphatase (ALK-P), aspartate aminotransferase (AST), alanine aminotransferase $(\mathrm{ALT})$, amylase, creatine kinase(CK), r-glutamyl transferase(GGT), and la ctate dehydrogenase(LDH) concentr ation in blood plasma during growth period of velvet antler in Korean $s$ potted deer.

속도로 떨어져 1주안에 평균 농도로 되돌아왔 다고 보고했으며 연중 antler cycle과 관련해서 비슷한 계절적 변화는 다른 사슴 종에서도 입 증되었다(Brown 등, 1978 ; Morris and Bubenik, 1983). 또한 암컷 chital deer의 평균 혈청 내 ALK-P 농도는 118U/L, 임신한 암컷은 149U/L 로 임신으로 활성치가 더 높았으며 수컷의 평 균 농도는 219U/L로 암컷보다 수컷의 농도가 높았고, 어린 암컷은 $319 \mathrm{U} / \mathrm{L}$, 어린 수컷은 $271 \mathrm{U} / \mathrm{L}$ 로 성축보다 성장기의 동물에서 높은 활 성치를 나타내었다. 특히 신생 자록은 2493U/L 를 나타내어 골 대사와 성장이 활발히 진행되 고 있음을 나타냈다. 본 연구에서도 ALK-P의 blood level과 antler cycle 사이의 밀접한 관계가 확립되었다(Graham 등, 1962; Morris와 Bubenik, 1983)는 연구보고와 흰꼬리사슴에서 serum ALK-P activity와 hydroxyproline levels은 뿔 성 장기간 동안에 증가했다(Eems 등, 1988)는 연구 보고와 비슷한 경향을 나타내어 녹용성장 기간 동안 농도가 꾸준히 증가하여 녹용성장과 ALK-P 농도와 정의 상관관계를 나타내었다.

꽃사슴의 혈장 내 Aspartate aminotransferase (AST) 농도는 낙각 직후 $72.58 \mathrm{U} / \mathrm{L}$ 이었고 그 후 
증가하여 10 일에 $79.0 \mathrm{U} / \mathrm{L}, 20$ 일에 $78.67 \mathrm{U} / \mathrm{L}, 30$ 일에 $97.0 \mathrm{U} / \mathrm{L}$ 를 나타내어 녹용성장기간 중 가 장 높았으며 이 후 감소하여 낙각 후 40 일에 $58.67 \mathrm{U} / \mathrm{L}$ 를 나타내었고 50 일에는 $72.19 \mathrm{U} / \mathrm{L}$ 로 다시 증가하였으나 낙각 직후와 비교하여 녹용 성장에 따른 유의차는 나타나지 않았다. Alanine aminotransferase(ALT)의 혈장 내 농도는 낙 각 직후 $49.75 \mathrm{U} / \mathrm{L}$ 였고 10 일까지 약간 증가하여 $53.67 \mathrm{U} / \mathrm{L}$ 를 나타내었으나 그 후 감소하여 20일 에 53.33U/L, 30일에 50.67U/L, 40일에 47.0U/L, 50 일에 $46.56 \mathrm{U} / \mathrm{L}$ 를 각각 나타내어 낙각 후 10 일 경 이후 꾸준히 감소하였으나 낙각 직후와 비교하여 성장일수에 따른 유의차는 나타나지 않았다. Chital deer의 혈청 내 평균 ALT 활성 은 암컷이 51U/L, 임신한 암컷은 $26 \mathrm{U} / \mathrm{L}$, 어린 암컷 119U/L, 수컷 57U/L, 어린 수컷 63U/L, 신 생 자록 55U/L로 성축보다 한창 성장중인 사슴 의 활성치가 더 높았다. 본 연구에서 공시된 꽃사슴의 혈장 내 ALT 활성은 $40.86-53.67 \mathrm{U} / \mathrm{L}$ 의 범위로 이는 수컷 chital deer의 농도와 비슷 했으나, 겨울을 지낸 reindeer의 1 월과 3 월의 농 도보다는 낮은 값을, 11 월과 4월의 농도보다는 높은 값을 나타내었으며(Soveri 등, 1992) 낙각 후 녹용성장에 따른 유의차는 나타나지 않았 다.

꽃사슴의 혈장 내 amylase의 농도는 낙각 직후 289.67U/L였고 낙각 후 일수가 경과하면서 감소 와 증가를 반복하여 낙각 후 10 일에 $262.67 \mathrm{U} / \mathrm{L}$, 20일에 278.67U/L, 30일에 276.33U/L, 40일에 267.0U/L, 50일에 290.19U/L로 각각 낙각 직후 와 비교하여 녹용성장 일수에 따른 유의차는 나타나지 않았다.

Creatine kinase(CK)의 낙각 직후 농도는 $284.83 \mathrm{U} / \mathrm{L}$ 였고 낙각 후 10 일에 $306.0 \mathrm{U} / \mathrm{L}, 20$ 일 에 203.0U/L를 나타내었으며 30일에 223.0U/L, 40 일에 $216.0 \mathrm{U} / \mathrm{L}, 50$ 일에 $269.0 \mathrm{U} / \mathrm{L}$ 를 각각 나타 내어 증가와 감소를 반복하였으나 낙각 직후와 비교하여 녹용성장에 따른 유의차는 나타나지 않았다. CK는 근육 수축에 관여하는 에너지원 인 creatine phosphate의 합성 및 분해를 촉매하 는 효소로써, 동물체내에서 주로 골격근, 심근, 뇌 및 평활근에 고농도로 존재하는 효소이다.
즉 $\mathrm{CK}$ 의 활성은 운동종류 및 운동량에 따라 변화의 폭이 매우 크게 나타난다. 따라서 chital deer에서 길들여진 사슴보다 길들여지지 않은 사슴의 혈청 내 CK 활성이 높게 나타나고 포 획한 암컷 red deer와 사육된 암컷 red deer의 $\mathrm{CK}$ 활성은 차이가 나타난다(Zomborszky 등, 1996). Chapple 등(1991)이 측정한 길들여진 chital deer의 경우 CK 활성은 암컷 372U/L, 임 신한 암컷 $317 \mathrm{U} / \mathrm{L}$, 어린 암컷 $434 \mathrm{U} / \mathrm{L}$, 수컷 $326 \mathrm{U} / \mathrm{L}$, 어린 수컷 $294 \mathrm{U} / \mathrm{L}$ 였고, 길들여지지 않 은 chital deer의 CK 활성은 암컷 1623U/L, 어 린 암컷 $7400 \mathrm{U} / \mathrm{L}$, 수컷 $2,850 \mathrm{U} / \mathrm{L}$, 신생 자록 $838 \mathrm{U} / \mathrm{L}$ 로 길들여진 사슴보다 길들여지지 않은 사슴이 훨씬 높은 활성을 나타내어 사육조건이 나 환경에 따른 $\mathrm{CK}$ 활성치는 차이가 있었으나, 본 연구에서와 같이 동일한 사육조건 하에서는 녹용성장과 $\mathrm{CK}$ 활성과는 특별한 상관관계가 없는 것으로 나타났다.

Lactate dehydrogenase(LDH)의 혈장 내 농도는 낙각 직후에 $328.75 \mathrm{U} / \mathrm{L}$ 였고 낙각 후 10 일에 $430.0 \mathrm{U} / \mathrm{L}(\mathrm{I}<0.01)$ 로 급격한 증가를 나타내었다 가, 20 일에 $354.67 \mathrm{U} / \mathrm{L}$ 로 급격히 감소하였고 이 후 다시 증가하여 30 일에 $426.0 \mathrm{U} / \mathrm{L}, 40$ 일에 $389.33 \mathrm{U} / \mathrm{L}, 50$ 일에 $370.38 \mathrm{U} / \mathrm{L}$ 를 각각 나타내어 증가와 감소를 반복하였으며 낙각 직후와 비교 하여 녹용성장에 따른 유의차는 낙각 후 10 일 째 측정치에서만 인정되었다. $\mathrm{LDH}$ 도 동물체에 서 조직에 널리 분포하는 효소로, 여러 장기에 널리 분포하는 장기 특이성이 낮은 효소이다. 이들 근육 효소들은 운동이나 포획시의 심한 스트레스, 장애 등에 의해서 혈액으로 방출된 다. chital deer의 LDH 활성은 암컷 453U/L, 임 신한 암컷 $331 \mathrm{U} / \mathrm{L}$, 어린 암컷 $1,017 \mathrm{U} / \mathrm{L}$, 수컷 486U/L, 어린 수컷 569U/L, 신생 자록 978U/L 로 암컷보다 수컷이, 성축보다 성장기의 동물 에서 활성이 더 컸다. 본 연구에 공시한 꽃사 슴은 실험 전의 순치와 잦은 handling으로 인해 많이 순화되었기 때문에 $\mathrm{CK}, \mathrm{LDH}$ 활성이 비교 적 안정적으로 유지되었다고 여겨진다. 이 $\mathrm{CK}$, $\mathrm{LDH}$ 활성은 다른 동물들의 활성과 비교해 볼 필요가 있는 것으로 사람의 $\mathrm{CK}$ 의 정상 범위는 남자 25-140U/L, 여자 20-120U/L, 말 2.4- 
$23.4 \mathrm{U} / \mathrm{L}$, 소 $4.8-12.1 \mathrm{U} / \mathrm{L}$, 양 $8.1-12.9 \mathrm{U} / \mathrm{L}$, 염 소 $0.8-8.9 \mathrm{U} / \mathrm{L}$ 이고, $\mathrm{LDH}$ 활성은 말 $162-$ $412 \mathrm{U} / \mathrm{L}$, 소 $692-1,445 \mathrm{U} / \mathrm{L}$, 양 $238-440 \mathrm{U} / \mathrm{L}$, 염 소 $123-392 \mathrm{U} / \mathrm{L}$ 였는데 반해, 레드디어의 $\mathrm{CK}$ 농도 범위는 각각 $83-383 \mathrm{U} / \mathrm{L}, 23-1,054 \mathrm{U} / \mathrm{L}$, 20 - 3,062U/L, fallow deer $40-5,280 \mathrm{U} / \mathrm{L}$, rusa deer $123-604 \mathrm{U} / \mathrm{L}, \mathrm{LDH}$ 의 농도 범위는 레드디 어 $550-1,463 \mathrm{U} / \mathrm{L}$ 로, $\mathrm{LDH}$ 활성도 다른 동물보 다 사슴 종의 활성이 높지만, 특히 CK 활성은 다른 동물에 비해서 본 연구결과와 같이 사슴 종이 훨씬 높은 활성치를 나타내었다. 일반적 으로 $\mathrm{CK}$ 와 $\mathrm{LDH}$ 는 근육이나 심장 질환이 나타 날 경우에 활성이 높아지는데 정상적인 사슴에 서 이들의 활성이 다른 동물보다 높다는 점은 사슴 종에게 나타나는 특이한 생리적 현상이라 고 생각되며, 앞으로 다른 야생 동물들과 비교 해 볼 필요가 있다고 생각된다. 그러나 녹용성 장과 이들의 활성과는 상관관계가 나타나지 않 았다.

$\gamma$-glutamyl transferase(GGT)는 기질인 $\gamma$-glutamyl peptide의 $\gamma$-glutamyl기를 다른 아미노산이나 펩 타이드로 전이시키는 막 결합 효소로, 아미노 산의 재흡수, 수송, glutathione 가수분해 등의 역할을 하는 효소로 동물체의 조직 내에 신세 뇨관 brush border membrane에 가장 많이 존재 한다(이와 이, 1996). 꽃사슴의 혈장 내 GGT 활성은 낙각 직후 $19.08 \mathrm{U} / \mathrm{L}$ 였고 이후 증가하 여 낙각 후 10 일에 $20.0 \mathrm{U} / \mathrm{L}, 20$ 일에 $24.0 \mathrm{U} / \mathrm{L}$ 를 나타내었으나 이후 감소하여 30 일에 $23.67 \mathrm{U} / \mathrm{L}$, 40일에 $18.33 \mathrm{U} / \mathrm{L}$ 를 나타내었고 50일에는 20.19 $\mathrm{U} / \mathrm{L}$ 로 다시 증가하였으나 낙각 직후와 비교하 여 녹용성장에 따른 유의차는 나타나지 않았 다.

이상과 같이 사슴의 녹용성장기간동안의 혈 액 중 효소 활성치를 검토해 본 결과 ALK-P의 활성은 녹용성장과 함께 증가하였으나 다른 효 소들은 큰 변화가 나타나지 않았다.

\section{$\mathrm{VI}$ 요 약}

본 연구는 축사 내에서 집약적으로 사육되고 있는 꽃사슴의 녹용 성장기간 중의 혈액성분변
화와 녹용성장과의 관련성 해석을 위한 기초자 료를 제공하고자 수행하였다. 녹용성장기간 중 혈액성분의 변화를 측정하기 위하여 우리 내에 서 사육 중인 $4 \sim 6$ 년 생 꽃사슴 웅록 25두를 무작위로 선별하여, 낙각 직후부터 10 일 간격 으로 절각일(50일)까지 혈액을 채취하여 미네랄 과 효소 활성치를 측정하였다. 칼슘과 인의 농 도는 녹용성장기간 중 커다란 변동이 없었으며 나트륨, 칼륨, 염소의 농도는 낙각 직후와 녹용 성장에 따른 경시적인 유의차가 나타났다. AST, $\mathrm{ALT}$, amylase, CK, GGT 및 $\mathrm{LDH}$ 의 농도는 낙 각 직후와 녹용성장에 따른 유의차는 인정되지 않았으나, ALK-P의 농도는 녹용성장이 진행되 면서 계속 증가하여 낙각 후 50일 경에는 최고 치를 나타내어 낙각시의 농도와 유의차가 나타 났으며(F〈0.01), $\mathrm{CK}$ 와 $\mathrm{LDH}$ 의 활성은 다른 동 물들보다 높게 나타났다.

\section{$\mathrm{V}$ 인 용 문 헌}

1. Anderson, A. E., Medin, D. E. and Browden, D. C. 1972. Blood serum electrolytes in a Colorado mule deer population. J. Wildl. Dis. 8:183-190.

2. Audige, L. 1992. Serum biochemical values of rusa deer(Cervus timorensis rusa) in New Caledonia. Australian Veterinary Journal. 69:268-271.

3. Banks, W. J. and Newbrey, J. W. 1983. Antlers development as unique modification of mammalian endochondral ossification. In : brown $\mathrm{RD}(\mathrm{ed})$ Antler Development in Cervidae. Caesar Kleberg Research Institute, Kingsville, p 279.

4. Banks, W. J., Epling, G. P., Kainer, R. A. and Davis, R. W. 1968a. Antler growth and osteoporosis. I Morphological and morphometric changes in the costal compacta during the antler growth cycle. Anat. Rec. 162:387.

5. Banks, W. J., Epling, G. P., Kainer, R. A. and Davis, R. W. 1968b. Antler growth and osteoporosis. II Gravimetric and chemical changes in the costal compacta during antler growth cycle. Anat. Rec. 162:399.

6. Bronner, F. and Stein, W. D. 1995. Calcium homeostasis - An old problem revisited. J. Nutr. 125:1987s$1995 \mathrm{~s}$.

7. Brown, R. D., Chao, C. C. and Faulkner, L. W. 1983. Hormone levels and antler development in white - tailed and sika fawns. Comp. Biochem. Physiol. Vol.75A. No. 3, pp. 385-390.

8. Brown, R. D., Cowan, R. W. and Kavanaugh, J. F. 
1978. Effects of pinealectomy on seasonal androgen titers, antler growth and feed intake white-tailed deer. J. Anim. Sci. 47:435-440.

9. Chapple, R. S., English, A. W., Mulley, R. C. and Lepherd, E. E. 1991. Haematology and serum biochemistry of captive unsedated chital deer(Axis axis) in Australia. J. Wildl. Dise. 27: 396-406.

10. Chen, T. L., Hirst, M. A. and Feldman, D. 1979. A receptor-like binding macromolecule for 1,25dihydroxycholecalciferol in cultured mouse bone cells. J. Biol. Chem. 254:7491.

11. DelGiudice, G. D., Mech, L. D., Seal, U. S. and Karns, P. D. 1987. Effects of winter fasting and refeeding on white-tailed deer blood profiles. J. Wildl. Manage. 51(4):865-873.

12. Eems, V. D., Karen, L., Brown, R. D. and Gundberg, C. M. 1988. Circulating levels of 1,25-dihydroxyvitamin $\mathrm{D}$, alkaline phosphatase, hydroxyproline, and osteocalcin associated with antler growth in white-tailed deer. ActaEndocrinologica(Copenh), 118, 407-414.

13. Eiben, B., Scharla St, Fischer, K., SchmidtGayk, H. 1984. Seasonal variations oh serum 1,25dihydroxyvitamin D3 and alkaline phosphatase in relation to the antler formation in the fallow deer (Dama dama L.). Acta Endocrine(Copenh) 107:141.

14. Eiben, B. and Fischer, K. 1984. Untersuchung verschiedener Blutparameter beim Damhirsch(Dama dama L.) im Jahresgang. Z. Jagdwiss. 30:235-242.

15. Fritsch, J., Grosse, B., Lieberherr, M. and Balsan, S. 1985. 1,25-Dihydroxyvitamin D3 is required for growth independent expression of alkaline phosphatase in cultured rat osteoblasts. Calcif. Tissue Int. 37:369.

16. Garcia, R. M., Sadighi, M., Francis, S. M., Suttie, J. M. and Fleming, J. S. 1997. Expression of neurotrophin-3 in the growing velvet antler of the red deer Cervus e laphus. Journal of Molecular Endocrinology 19, 173182.

17. Glenn, D. D., Mech, L. D., Seal, U. S. and Karns, P. D. 1987. Effects of winter fasting and refeeding on white-tailed deer blood profiles. J. Wildl. Manage. 51(4):865-873.

18. Graham E. A., Rainey, R. K., Albert, E., Houghton, E. H. and Moyer, C. A. 1962. Biochemical investigations of deer antlar growth. Part I. Alternations of deer blood chemistry resulting from osteogenesis. J. Bone Jt Surg. 44A, 482-488.

19. Knox, D. P., McKelvey, W. A. and Jones, D. G. 1988. Blood biochemical reference values for farmed red deer. Veterinary Record. 122:109-112.

20. Kurihara, N., Ikeda, K., Hakeda, Y., Tsunoi, M., Maeda, N. and Kumegawa, M. 1984. Effects of 1,25 Dihydroxyvitamin D3 on alkaline phophatase activity and collagen synthesis in osteoblastic cells, clone MC3T3-E1. Biochem. Biophys Res Commun. 119:767.

21. Manolagas, S. C., Haussler, M. R. and Deftos, L.
J. 1980. 1,25 Dihydroxyvitamin D3 receptor-like macromolecule in rat osteogenic sarcoma cell lines. J. Biol. Chem. 255:4414.

22. Morris, J. M. and Bubenik, G. A. 1983. Seasonal levels of minerals, enzymes, nutrients and metabolic products in plasma of intact and castrated adult male white-tailde deer(Odocoileus virginianus). Comparative Biochemistry and Physiology. 74A:21-28.

23. Muir, P. D., Sykes, A. R. and Barrell, G. K. 1987. Growth and mineralization of antlers in red deer (Cervus elaphus). New Zealand J. Agric. Res.(In the Press).

24. Riggs, B. L. and Melton, L. J. 1986. Involutional osteoporosis. N. Engl J. Med. 314:1676-1686.

25. SAS package. 1985. SAS Institute Inc.

26. Seal, U. S., Verme, L. J. and Ozoga, J. J. 1987. Dietary protein and energy effects on deer fawn metabolic patterns. J. Wildl Manage. 42:776-790.

27. Seal, U. S., Verme, L. J., Ozoga, J. J. and Erickson, A. W. 1972. Nutritional effects on thyroid activity and blood of white-tailed deer. J. Wildl. Manage. 36:1041-1052.

28. Sempere, A. J., Bubenik, G. A. and Smith, J. H. 1986. Antler cycle and thermolabile and thermostable alkaline phosphatase in white-tailed deer; circannual and circadianrhythms and variation after thyroxine, dexamethasone and ACTH administration.Acta Endocrinologica, 111:133-139.

29. Sempere, A. J., Grimberg, R., Silve, C., Tau, C. and Garabedian, M. 1989. Evidence for extrarenal production of 1,25-dihydroxyvitamin during physiological bone growth: In Vivo and In Vitro production by deer antler cells. Endo. 125, No.5.

30. Soveri, T., Sankari, S. and Nieminen, M. 1992. Blood chemistry of reindeer calves(RANGIFER TARANDUS) during the winter season. Comp. Biochem. Physiol. 102A. 1:191-196.

31. Takigawa, M., Enomoto, M., Shirai, E., Nishii, Y. and Suzuki, F. 1988. Differential effects of 1a,25-dihydroxycholecalciferol and 24,25dihydroxycholecalciferol on the proliferation and the differentiation phenotype of rabbit costal chondrocytes in culture. Endocrinology. 122:831.

32. Wilson, P. R. and Pauli, J. V. 1982. Blood constituents of farmed red deer(Cervus elephus). I Haematological values. New Zealand Veterinary Journal. 30:174-176.

33. Zomborszky, Z., Feher, T., Eva Horn, Eva Poteczin, Tubolt, S. and Zomborszky, M. K. 1996. Comparison of some blood parameters of captured and farmed red deer (CERVUS ELAPHUS) hinds. Acta Veterinaria Hungarica. 44(4):433-441.

34. 신국현. 1987. 호범생약 연구보고서.

35. 이귀녕, 이종순. 1996. 임상병리파일.

(접수일자 : 2003. 9. 15. / 채택일자 : 2003. 12. 5.) 